University of Nebraska - Lincoln

DigitalCommons@University of Nebraska - Lincoln

Faculty Publications: Department of

Entomology

Entomology, Department of

2020

\title{
Integrated crop-livestock systems in paddy fields: New strategies for flooded rice nutrition
}

Luiz Gustavo de O. Denardin

Federal University of Rio Grande do Sul, luizgdenardin@gmail.com

Amanda P. Martins

Federal University of Rio Grande do Sul

Felipe de C. Carmona

Rio Grande do Sul

Murilo G. Veloso

Federal University of Rio Grande do Sul

Gabriela I. Carmona

University of Nebraska-Lincoln, gabriela.inveninato-carmona@huskers.unl.edu

See next page for additional authors

Follow this and additional works at: https://digitalcommons.unl.edu/entomologyfacpub

Part of the Agriculture Commons, Agronomy and Crop Sciences Commons, and the Entomology

Commons

Denardin, Luiz Gustavo de O.; Martins, Amanda P.; Carmona, Felipe de C.; Veloso, Murilo G.; Carmona, Gabriela I.; Carvalho, Paulo César de F.; and Anghinoni, Ibanor, "Integrated crop-livestock systems in paddy fields: New strategies for flooded rice nutrition" (2020). Faculty Publications: Department of Entomology. 855.

https://digitalcommons.unl.edu/entomologyfacpub/855

This Article is brought to you for free and open access by the Entomology, Department of at DigitalCommons@University of Nebraska - Lincoln. It has been accepted for inclusion in Faculty Publications: Department of Entomology by an authorized administrator of DigitalCommons@University of Nebraska - Lincoln. 


\section{Authors}

Luiz Gustavo de O. Denardin, Amanda P. Martins, Felipe de C. Carmona, Murilo G. Veloso, Gabriela I. Carmona, Paulo César de F. Carvalho, and Ibanor Anghinoni 


\title{
Integrated crop-livestock systems in paddy fields: New strategies for flooded rice nutrition
}

\author{
Luiz Gustavo de 0. Denardin, ${ }^{1}$ Amanda P. Martins, ${ }^{1}$ \\ Felipe de C. Carmona, ${ }^{2}$ Murilo G. Veloso, ${ }^{1}$ \\ Gabriela I. Carmona, ${ }^{3}$ Paulo César de F. Carvalho, ${ }^{4}$ \\ \& Ibanor Anghinoni ${ }^{1}$
}

\footnotetext{
1 Soil Science Department, Federal University of Rio Grande do Sul, 7712 Bento Gonçalves Avenue, Porto Alegre, Rio Grande do Sul, 91540000, Brazil 2 Estrada Silval, Capivari do Sul, Rio Grande do Sul, 95552000, Brazil 3 Department of Entomology, University of Nebraska-Lincoln, 1700 E Campus Mall, Lincoln, NE 68583, USA

4 Forage Plants and Agrometeorology Department, Federal University of Rio Grande do Sul, 7712 Bento Gonçalves Avenue, Porto Alegre, Rio Grande do Sul, 91540000, Brazil

Corresponding author - Luiz Gustavo de 0. Denardin, Soil Science Department, Federal University of Rio Grande do Sul, 7712 Bento Gonçalves Avenue, 91540000, Porto Alegre, Rio Grande do Sul State, Brazil Email: luizgdenardin@gmail.com
}

ORCID Luiz Gustavo de O. Denardin https://orcid.org/0000-0002-0751-056X

\begin{abstract}
Integrated crop-livestock systems (ICLSs) appear as a good alternative to increase nutrient use efficiency (NUE) in rice (Oryza sativa L.) through the improvement in nutrient cycling and soil chemical attributes in paddy fields. The objective of this study
\end{abstract}

Published in Agronomy Journal 112 (2020), pp 2219-2229.

doi: $10.1002 /$ agj2.20148

Copyright (C) 2020 by the authors. Agronomy Journal is (C) 2020 by American Society of Agronomy; published by Wiley. Used by permission. 
was to evaluate the impact of an ICLS on soil chemical attributes and on the fertilization requirement of $\mathrm{N}, \mathrm{P}$, and $\mathrm{K}$ by flooded rice in the Brazilian subtropical region. $\mathrm{Nu}-$ tritional status, yield, and NUE of flooded rice were evaluated by fertilization trials through rice response to different fertilization rates of N, P, and K. Soil chemical attributes were evaluated at the beginning of the experiment and 30 mo later. Different fertilization rates were applied in two systems: (a) a conventional system (CS), based on intensive tillage, rice monocropping and winter fallow, and (b) ICLS, characterized by no-tillage and winter cattle grazing in annual ryegrass (Lolium multiflorum Lam.) pasture. Rice shoot accumulation of N, P, and K was greater under CS than ICLS at all fertilization levels. On the other hand, higher rice yields were observed under ICLS at almost every fertilization level, suggesting higher NUE than CS. In addition, rice yield was increased by $40 \%$ by fertilization of $\mathrm{P}$ and $\mathrm{K}$ under CS, whereas no response was observed under ICLS. These benefits were possibly related to greater nutrient cycling and greater synchronism between rice's nutrient uptake and nutrient release of the soil. Our results indicate that the adoption of ICLS ensures greater NUE becoming a system less dependent on external inputs.

\section{Core Ideas}

- The integrated crop-livestock system has different rice fertilization requirements.

- Rice in an integrated crop-livestock system does not respond to P and K fertilization.

- An integrated crop-livestock system has higher eco-efficiency than conventional system.

- Nitrogen remains a limiting nutrient for rice development and yield.

Abbreviations: CEC, cation exchange capacity, CS, conventional system, ICLS, integrated crop-livestock system, NUE, nutrient use efficiency, SOM, soil organic matter

\section{Introduction}

The requirements to increase global food production are well known and are projected to double by 2050, when World's population will likely reach nine billion people (FAOSTAT, 2013). According to Alexandratos and Bruinsma (2003), the annual increases in corn (Zea mays L.), soybean [Glycine max (L.) Merr.], and rice (Oryza sativa L.) production, which are three of the most important grain crops cultivated in the world, are insufficient to address the rising demand by 2050 and must increase 67,55 , and $42 \%$, respectively. This requirement will have to be achieved by using less land, water, labor, and chemicals (Khush, 2000).

Worldwide, rice corresponds to $29 \%$ of grain consumption, being the staple food of half of the population's diet in developing countries. Following a 35-yr trend, increases in rice production are expected to come 
from greater yields because rice acreage increased only $36.2 \%$, whereas its production increased 253\% (Alexandratos \& Bruinsma, 2003).

Outside of Asia, Brazil is the largest rice producer. In Brazil, rice is produced mainly in lowlands and floodplains in the subtropics (southern region) (FAOSTAT, 2013). Rio Grande do Sul State produces 61\% of Brazil's rice demand, where the conventional rice cropping system includes yearly soil tillage and fallow periods. Traditionally, this system may or not be combined with extensive and inefficient livestock production. In addition, the cultivation system is still based on intense and frequent soil disturbance. According to Boeni, Anghinoni, Genro Junior, and Osório Filho (2010), in all rice regions of Rio Grande do Sul State, there was a predominance $(71 \%)$ of areas with low soil organic matter $(\mathrm{SOM})$ content $(\leq 2.5 \%)$. In addition, the predominance of sandy texture soils on these areas is detrimental to rice yield performance due to lower soil cation exchange capacity (CEC), nutrient availability (Denardin et al., 2018), and soil microbiological activity (Martins et al., 2017).

Soil disturbance has been pointed out as the main cause of soil degradation worldwide (Lal, 2015). Cassman, De Datta, Olk, Alcantara, and Samson (1995) and Flinn and De Datta (1984) showed greater soil degradation in long-term experiments with soil disturbance in flooded rice cultivation systems due to lower $\mathrm{pH}, \mathrm{CEC}$, and nutrient use efficiency (NUE). Soil degradation consequently decreases rice yield over time (Bado, Aw, \& Ndiaye, 2010; Dobermann, Dawe, Roetter, \& Cassman, 2000). Thus, current flooded rice cropping systems require higher fertilizer levels to sustain high yields (Boeni et al., 2010). On the other hand, soils managed under no-tillage favor SOM accumulation and nutrients in the topsoil (Denardin et al., 2019; Feng et al., 2006; Tang et al., 2007) as well as better soil microbiological attributes (Gao et al., 2004; Martins et al., 2017).

Although the adoption of no-tillage provides improvements in soil quality through the increase of SOM content, rice yield under no-tillage requires 14 yr to surpass conventional tillage system yields (Denardin et al., 2019). Thus, the adoption of this practice alone does not increase rice crop yield, especially in the short term, and it is necessary to diversify the production system with other crops and/or activities (Denardin et al., 2019; Huang, Zhou, Cao, Xia, \& Zou, 2015).

Carmona, Anghinoni, Mezzari, Martins, and Carvalho (2016) found increases in yield and decreased rice response to fertilization under an 
integrated crop-livestock system (ICLS). The ICLS is based on rotation between grain crop under no-tillage and livestock under pasture cultivation (Carvalho et al., 2014). Pasture fertilization can optimize fertilizer use, determined by nutrient (re)cycling through grazing, consequently improving soil fertility (Assmann et al., 2017; Carvalho et al., 2010).

Our hypothesis is that ICLSs, based on no-tillage and winter grazing, result in greater NUE compared with the conventional system (CS) of flooded rice. The objective of the study was to evaluate the impact of an ICLS (under no-tillage combined with winter grazing) on soil chemical attributes and on the fertilization requirement of N, P, and $\mathrm{K}$ by flooded rice in the Brazilian subtropical region.

\section{Materials and methods}

\subsection{Site description and historical characterization of the experimental area}

An on-farm field trial was conducted in the 2015/2016 and 2016/2017 rice growing seasons at Corticeiras Farm, located in Cristal City, Rio

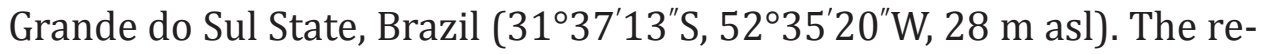
gional climate is a warm humid summer climate, classified as Cfa, according to Köppen (Kottek, Grieser, Beck, Rudolf, \& Rubel, 2006). The mean annual temperature is $18.3^{\circ} \mathrm{C}$, and the mean annual rainfall is 1522 $\mathrm{mm}$ (30-yr normal) (Matzenauer et al., 2011). The soil is poorly drained, classified as Albaqualf (Soil Survey Staff, 2010), with sandy clay loam texture $(24,23$, and $53 \%$ of clay, silt, and sand, respectively).

The experimental area has been cultivated with flooded rice followed by fallow since 1962 . The last rice cropping season before the study was in 2009, followed by a fallow period until March 2013, when soil samples (0-10 cm soil layer) were taken for chemical characterization of the experimental site. In April 2013, the soil in the entire area was tilled with three heavy discs to incorporate lime applied at a rate of $4.5 \mathrm{Mg} \mathrm{ha}^{-1}$ (with a total neutralization relative power of 70\%), determined according to CQFS RS/SC (2004), to increase the $0-20$-cm soil layer to $\mathrm{pH} 6.0$.

After soil $\mathrm{pH}$ correction, five production systems involving the cultivation of flooded rice were established in an 18-ha area. For the present study, only two of the five systems were evaluated: (a) CS, which is 
the dominant system in the lowlands of southern Brazil, based on intensive soil disturbance, rice monocropping, and winter fallow period, and (b) ICLS, which is characterized by no-tillage adoption and integration between crop and livestock, with annual ryegrass pasture grazing during the winter season. Before the present study, there were two pasture seasons in the ICLS (winter 2013 and 2014) and two rice-growing seasons in both systems (2013/2014 and 2014/2015 cropping seasons).

\subsection{Treatment description and experimental design}

In the 2015/2016 cropping season, five different levels of NPK fertilization were applied in both systems (CS and ICLS) based on expected yield response to fertilization of flooded rice, according to SOSBAI (2014). Fertilization levels corresponded to different fertilizer rates (in $\mathrm{kg} \mathrm{ha}^{-1}$ of $\mathrm{N}-\mathrm{P}_{2} \mathrm{O}_{5}-\mathrm{K}_{2} \mathrm{O}$ ), according to SOSBAI (2014): (a) no fertilizer application, (b) low expected yield response to fertilization (60-20-20), (c) medium expected yield response to fertilization (90-30-35), (d) high expected yield response to fertilization (120-40-50), and (e) very high expected yield response to fertilization (150-50-65). Fertilizer sources used were urea $(46 \% \mathrm{~N})$, single superphosphate $\left(18 \% \mathrm{P}_{2} \mathrm{O}_{5}\right)$, and potassium chloride $\left(60 \% \mathrm{~K}_{2} \mathrm{O}\right)$. The experimental design was conducted as a split plot randomized complete block design with four replications. The experimental subplot size was $5 \mathrm{~m}$ by $5 \mathrm{~m}$.

Due to the results obtained in the first cropping season, another experiment was carried out in the second cropping season (2016/2017) to separate the effects of $\mathrm{P}$ and $\mathrm{K}$ from $\mathrm{N}$ fertilization. For this, two treatments were designed to evaluate the rice response to the presence or absence of $\mathrm{P}$ and K supply (150-70-120 and 150-00-00, in kg ha-1 of N$\mathrm{P}_{2} \mathrm{O}_{5}-\mathrm{K}_{2} \mathrm{O}$, respectively), fertilized with the recommended $\mathrm{N}$ rate $(150 \mathrm{~kg}$ $\mathrm{N} \mathrm{ha}^{-1}$ ). In addition, four treatments were established providing different N rates: (a) 0-70-120, (b) 50-70-120, (c) 100-70-120, and (d) 150-70120 (in kg ha-1 of $\mathrm{N}-\mathrm{P}_{2} \mathrm{O}_{5}-\mathrm{K}_{2} \mathrm{O}$ ), respectively. All fertilizer sources used were the same in both production systems, as were the experimental design and subplot size.

The $\mathrm{N}$ rates were split into two applications: $66 \%$ applied at $\mathrm{V}_{3}$ phenological stage, immediately before flooding, and $33 \%$ applied at $V_{8}$ phenological stage. The rice stages were determined according to Counce, Keisling, and Mitchell (2000). The IRGA 430 rice cultivar was used in 
the first cropping season, and the IRGA 424 cultivar was used in the second cropping season, seeded at a density of $100 \mathrm{~kg} \mathrm{ha}^{-1}$ in a $17 \mathrm{~cm}$ row spacing. The rice planting and harvest occurred in November 2015 and April 2016, respectively, in the 2015/2016 growing season and in October 2016 and March 2017, respectively, in the 2016/2017 growing season. Agronomic management for weed, insects, and disease control was done according to the technical recommendations (SOSBAI, 2014).

Neutered male steers (Angus; Bos taurus) weighing around $200 \mathrm{~kg}$ were used for grazing in ICLS in both winter seasons (2015 and 2016). Average adopted pasture height was $15 \mathrm{~cm}$, and average stocking rate was $831 \pm 114 \mathrm{~kg}$ live weight ha-1, simulating cattle fattening or finishing systems during $62 \pm 15 \mathrm{~d}$. The cattle's diet was forage based, with only mineral salt being provided. Continuous grazing was adopted (with a minimum of three test steers), and annual ryegrass was re-sowed at a density of $30 \mathrm{~kg} \mathrm{ha}^{-1}$ using the BRS Ponteio cultivar. Ryegrass fertilization was done according to CQFS RS/SC (2004) recommendations, with 110-110-100, 130-130-130, 120-120-120, and 120-120-120 kg ha-1 of $\mathrm{N}-\mathrm{P}_{2} \mathrm{O}_{5}-\mathrm{K}_{2} \mathrm{O}$ in the $2013,2014,2015$, and 2016 winter seasons, respectively. Rice fertilization in the 2013/2014 and 2014/2015 summer seasons was according to SOSBAI recommendations (SOSBAI, 2014), representing 150-70-120 $\mathrm{kg} \mathrm{ha}^{-1}$ of $\mathrm{N}-\mathrm{P}_{2} \mathrm{O}_{5}-\mathrm{K}_{2} \mathrm{O}$, respectively.

\subsection{Soil analyses}

The soil was sampled in March 2013, prior to the installation of the experiment. Soil samples (up to 10 -cm soil layer) were composed by six subsamples per plot. Georeferenced samples were collected in a sample grid of $2025 \mathrm{~m}^{2}$. In October 2015, before the first rice crop season, soil samples were collected at the same georeferenced points.

Soil samples were transported in plastic bags to the Federal University of Rio Grande do Sul's Soil Fertility Research Laboratory. The samples were dried in a forced-air circulation oven at $50^{\circ} \mathrm{C}$, ground, sieved through 2-mm mesh, and analyzed. The soil properties used for the soil fertility evaluation were: $\mathrm{pH}$ in water, SOM content (wet combustion), available $\mathrm{P}$ and $\mathrm{K}$ (extracted by Mehlich-1), exchangeable Ca and $\mathrm{Mg}$ (extracted by $1.0 \mathrm{~mol} \mathrm{~L}^{-1} \mathrm{KCl}$ ), $\mathrm{CEC}_{\mathrm{pH} 7.0}$, and base saturation (V\%). All analyses were performed following the methodology described by Tedesco, Gianello, Bissani, Bohnen, and Volkweiss (1995). Exchangeable $\mathrm{Al}^{3+}$ was determined by titration with $0.0125 \mathrm{~mol} \mathrm{~L}^{-1} \mathrm{NaOH}$ solution, $\mathrm{Ca}^{2+}$ and 
$\mathrm{Mg}^{2+}$ by atomic absorption spectrometry, $\mathrm{K}$ by flame photometry, and $\mathrm{P}$ by photocolorimetry. Potential acidity $(\mathrm{H}+\mathrm{Al})$ was obtained through the equation proposed by Kaminski, Rheinheimer, and Bartz (2001). The sum of bases was determined by the sum of $\mathrm{Ca}, \mathrm{Mg}$, and $\mathrm{K}$. The CE$\mathrm{C}_{\mathrm{pH7.0}}$ was calculated by sum of bases $+(\mathrm{H}+\mathrm{Al})$; V\% was calculated using the relation: $\mathrm{V} \%=100 \times$ sum of bases $/ \mathrm{CEC}_{\mathrm{pH} 7.0}(\mathrm{CQFS}-\mathrm{RS} / \mathrm{SC} 2016)$.

\subsection{Plant analyses}

In the first cropping season (2015/2016), rice tissue samples were collected to evaluate the dynamics of absorption of different nutrients. The first plant sampling occurred at the $\mathrm{R} 4$ rice stage (Counce et al., 2000) to evaluate rice's nutritional status, nutrient accumulation, and shoot dry matter. For crop nutritional status evaluation, 50 rice flag leaves were collected per experimental unit. For nutrient accumulation and shoot dry matter evaluation, rice plants were sampled from $0.15 \mathrm{~m}^{2}$ per plot at the beginning of flowering (R4 stage). Samples were oven dried (forced air at $\left.65^{\circ} \mathrm{C}\right)$, weighed, ground, and sieved $(\varnothing=0.5 \mathrm{~mm})$. Nitrogen, $\mathrm{P}$, and $\mathrm{K}$ content in plant tissue was analyzed after chemical digestion $\mathrm{CH}_{2} \mathrm{O}_{2}+$ $\mathrm{H}_{2} \mathrm{SO}_{4}$ ) according to Tedesco et al. (1995). Nutrient accumulation was calculated using data obtained from the whole plant (Equation 1).

$$
\mathrm{NA}=\mathrm{SNC} \times \mathrm{SDMP}
$$

where NA is nutrient accumulation $\left(\mathrm{kg} \mathrm{ha}^{-1}\right)$, SNC is shoot nutrient content $\left(\mathrm{kg} \mathrm{Mg}^{-1}\right)$, and SDMP is shoot dry matter production $\left(\mathrm{Mg} \mathrm{ha}^{-1}\right)$.

The second plant sampling took place at $R_{7}-R_{8}$ rice stage (Counce et al., 2000) in the 2015/2016 and 2016/2017 cropping seasons to determine grain yield. Harvests were performed by hand, with plants sampled from $1.02 \mathrm{~m}^{2}$ per plot. Samples were threshed, cleaned, and weighed. Grain moisture was determined and adjusted to $130 \mathrm{~g} \mathrm{~kg}^{-1}$.

The N, P, and K use efficiency rates were obtained by determining the amount of grain produced per each kilogram of nutrient accumulated in rice shoot dry matter (Equation 2).

$$
\mathrm{NUE}=\mathrm{GY} / \mathrm{NA}
$$

where NUE is nutrient use efficiency (kg grain kg nutrient ${ }^{-1}$ ), GY is grain yield $\left(\mathrm{kg} \mathrm{ha}^{-1}\right)$, and NA is nutrient accumulation $\left(\mathrm{kg} \mathrm{ha}^{-1}\right)$. 


\subsection{Statistical analyses}

Statistical analyses were performed using linear models (PROC GLM) of the Statistical Analysis System (SAS Institute, 1997). Data were assessed using the Shapiro-Wilk normality test $(p<.05)$, Levene's homogeneity of variance test $(p<.05)$, and ANOVA at $p<.05$. When significant, means were compared using Tukey's test $(p<.05)$.

\section{Results}

\subsection{Soil fertility attributes}

The short-term (30 mo) adoption of flooded rice cultivation increased the available $\mathrm{K}$, exchangeable $\mathrm{Ca}$ and $\mathrm{Mg}$, and $\mathrm{V} \%$ levels in both systems at rates of 71.2, 62.8, 27.3, and 29.8\%, respectively (Table 1). The SOM content, $\mathrm{pH}$ in water, and CEC did not change with time. The ICLS improved the available $P$ content from 9.9 to $26.1 \mathrm{mg} \mathrm{dm}^{-3}$, whereas CS did not alter available $P$ content.

Table 1 Soil fertility (0-10 cm layer) after 30 mo (March 2013 and October 2015) of the adoption of conventional system (CS) and integrated crop-livestock system (ICLS) production systems in paddy fields of a Brazilian subtropical region

\begin{tabular}{|c|c|c|c|c|c|c|c|c|}
\hline \multirow{2}{*}{$\begin{array}{l}\text { Production } \\
\text { system }\end{array}$} & \multirow{2}{*}{$\begin{array}{c}\text { SOM }^{a} \\
\%\end{array}$} & \multirow{2}{*}{ pH } & $\mathbf{P}$ & $\mathbf{K}$ & $\mathrm{Ca}$ & Mg & CEC $^{\mathbf{b}}$ & \multirow{2}{*}{$\begin{array}{c}\mathrm{V} \%{ }^{\mathrm{c}} \\
\%\end{array}$} \\
\hline & & & \multicolumn{2}{|c|}{$\mathrm{mg} \mathrm{kg}^{-1}$} & \multicolumn{3}{|c|}{$\mathrm{cmol}_{\mathrm{c}} \mathrm{kg}^{-1}$} & \\
\hline \multicolumn{9}{|c|}{ Mar. 2013} \\
\hline CS & 2.0 & 5.5 & $9.2 \mathrm{Aa}$ & 69.3 & 3.2 & 2.1 & 9.3 & 58.1 \\
\hline ICLS & 1.8 & 5.4 & $9.9 \mathrm{Ba}$ & 76.6 & 3.7 & 2.3 & 11.0 & 56.1 \\
\hline Average & 1.9 & 5.5 & 9.5 & $72.9 \mathrm{~B}$ & $3.5 \mathrm{~B}$ & $2.2 \mathrm{~B}$ & 10.2 & $57.1 \mathrm{~B}$ \\
\hline \multicolumn{9}{|c|}{ Oct. 2015} \\
\hline CS & 2.2 & 5.7 & $16.4 \mathrm{Ab}$ & 116.0 & 5.1 & 2.6 & 10.6 & 75.3 \\
\hline ICLS & 2.2 & 5.5 & 26.1Aa & 133.6 & 6.2 & 3.0 & 12.4 & 72.9 \\
\hline Average & $2.1 \mathrm{~ns}$ & $5.6 \mathrm{~ns}$ & 21.2 & $124.8 \mathrm{~A}$ & $5.7 \mathrm{~A}$ & $2.8 \mathrm{~A}$ & $11.5 \mathrm{~ns}$ & $74.1 \mathrm{~A}$ \\
\hline
\end{tabular}

Tukey's test $(p<.05)$. Different lowercase letters indicate differences between the flooded rice production systems within each year. Different uppercase letters indicate differences between years within each flooded rice production systems. ns, no statistical difference.

a. Soil organic matter.

b. Cation exchange capacity.

c. Base saturation. 

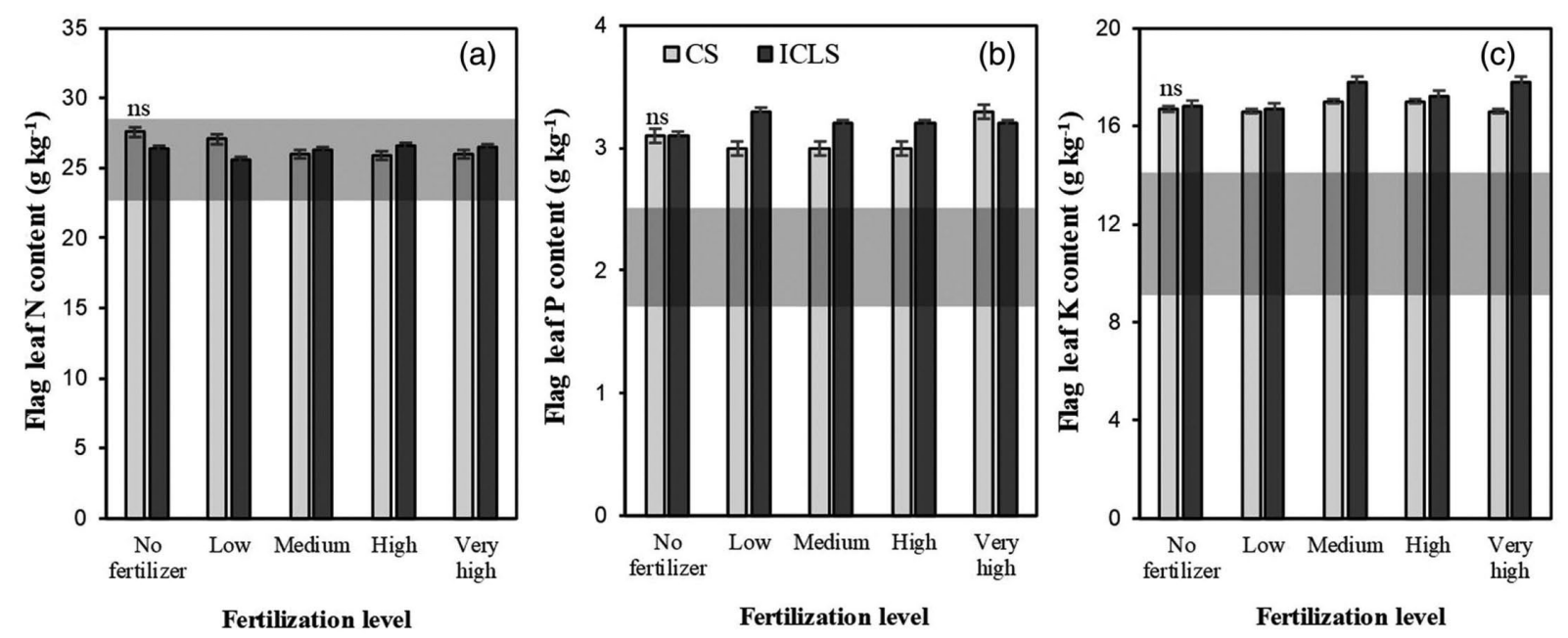

Figure 1 Flag leaf (a) nitrogen, (b) phosphorus, and (c) potassium contents affected by fertilization levels in the 2015/2016 cropping season of different flooded rice production systems in the Brazilian subtropics. The range highlighted in gray corresponds to the crop adequate nutritional status, according to SOSBAI (2014). Error bars represent SEM ( $\mathrm{n}=3)$. CS, conventional system; ICLS, integrated crop-livestock system; ns, no statistical difference according to Tukey's test $(p>.05)$.

\subsection{Nutritional status and nutrient accumulation}

The different input rates of $\mathrm{N}, \mathrm{P}$, and $\mathrm{K}$ fertilizer did not affect ( $p=.94$ ) the nutritional status of rice measured in the flag leaf (Figure 1), and the two rice production systems also remained similar to each other. The $\mathrm{N}, \mathrm{P}$, and $\mathrm{K}$ flag leaf content showed averages of 26.4, 3.1, and $17.0 \mathrm{~g} \mathrm{~N}$, $\mathrm{P}$, and $\mathrm{K} \mathrm{kg}^{-1}$, respectively.

Despite no differences in nutrient content measured in rice flag leaf (Figure 1), nutrient accumulation in the whole plant at R4 stage was significantly different among the production systems and fertilization levels (Table 2). For N, fertilization levels' effect was only significant under CS, where the highest response was obtained at the low fertilization level, achieving an increase of $65 \%$ compared with no fertilizer addition. However, $\mathrm{N}$ content at the low-fertilization level did not differ from medium and high fertilization levels. On the other hand, at the very high level of fertilization, there was a decrease in $\mathrm{N}$ accumulation, becoming similar to the no-fertilizer treatment. In ICLS, only medium and very high fertilization levels showed higher $\mathrm{N}$ accumulation than the no-fertilizer treatment. Higher $\mathrm{N}$ accumulation was observed in CS than in ICLS at low and high fertilization levels, with 52 and $33 \mathrm{~kg} \mathrm{~N} \mathrm{ha}^{-1}$, respectively (Table 2). 
Table 2 Nitrogen, phosphorus, and potassium accumulation in shoot dry matter of flooded rice affected by fertilization levels in the $2015 / 2016$ cropping season of different production systems in the Brazilian subtropics

Fertilization level

\begin{tabular}{|c|c|c|c|c|c|c|}
\hline \multirow{2}{*}{ Production system ${ }^{a}$} & & \multirow[b]{2}{*}{ Average } \\
\hline & No fertilizer & Low & Medium & High & Very high & \\
\hline \multicolumn{7}{|c|}{ Nitrogen kg ha ${ }^{-1}$} \\
\hline $\mathrm{CS}$ & $90 \mathrm{Ab}$ & 149Aa & $137 \mathrm{Aa}$ & $134 \mathrm{Aa}$ & $125 \mathrm{Aab}$ & 127 \\
\hline ICLS & $76 \mathrm{Ab}$ & 97Bab & $134 \mathrm{Aa}$ & 101Bab & $124 \mathrm{Aa}$ & 106 \\
\hline Average & 83 & 133 & 135 & 117 & 124 & \\
\hline \multicolumn{7}{|c|}{ Phosphorus kg ha-1 } \\
\hline $\mathrm{CS}$ & $29 \mathrm{Ab}$ & $42 \mathrm{Aa}$ & $36 \mathrm{Aab}$ & 33Aab & 41Aab & 36 \\
\hline ICLS & 28Ans & $31 \mathrm{~B}$ & $36 \mathrm{~A}$ & $33 \mathrm{~A}$ & $30 \mathrm{~B}$ & 31 \\
\hline Average & 29 & 36 & 36 & 33 & 36 & \\
\hline \multicolumn{7}{|c|}{ Potassium kg ha-1 } \\
\hline $\mathrm{CS}$ & 179 & 233 & 213 & 189 & 214 & $206 \mathrm{~A}$ \\
\hline ICLS & 160 & 190 & 202 & 170 & 194 & $183 B$ \\
\hline Average & $169 n s$ & 212 & 207 & 180 & 204 & \\
\hline
\end{tabular}

Tukey's test $(p<.05)$. Different lowercase letters indicate differences among the fertilization levels within each flooded rice production system. Different uppercase letters indicate differences between flooded rice production systems within each fertilization level. ns, no statistical difference.

a. CS, conventional system; ICLS, integrated crop-livestock system.

Different from ICLS, P accumulation in shoot dry matter in CS showed responses depending on different fertilization levels. At the low fertilization level, $\mathrm{P}$ accumulation was $45 \%$ higher than with the no-fertilizer treatment. In the low and very high fertilization levels, $P$ accumulation in rice shoot dry matter was on average $11 \mathrm{~kg} \mathrm{P} \mathrm{ha}^{-1}$ higher in CS compared with ICLS. Regarding K accumulation, regardless of fertilization levels, $\mathrm{K}$ accumulation in CS was $23 \mathrm{~kg} \mathrm{~K} \mathrm{ha}^{-1}$ higher than with ICLS (Table 2).

\subsubsection{Rice shoot dry matter and grain yield}

Rice shoot dry matter was not affected by fertilization levels in the ICLS (average rate, 10.8 $\mathrm{Mg} \mathrm{ha}^{-1}$ ) (Figure 2). In contrast, the increase in fertilization levels under CS resulted in an increase of rice shoot dry matter. In this system, the very high fertilization level resulted in $50 \%$ higher production than the no-fertilizer control. The low, medium, and high fertilization levels showed a similar shoot biomass, not differing from the other fertilization levels. Differences between the production 


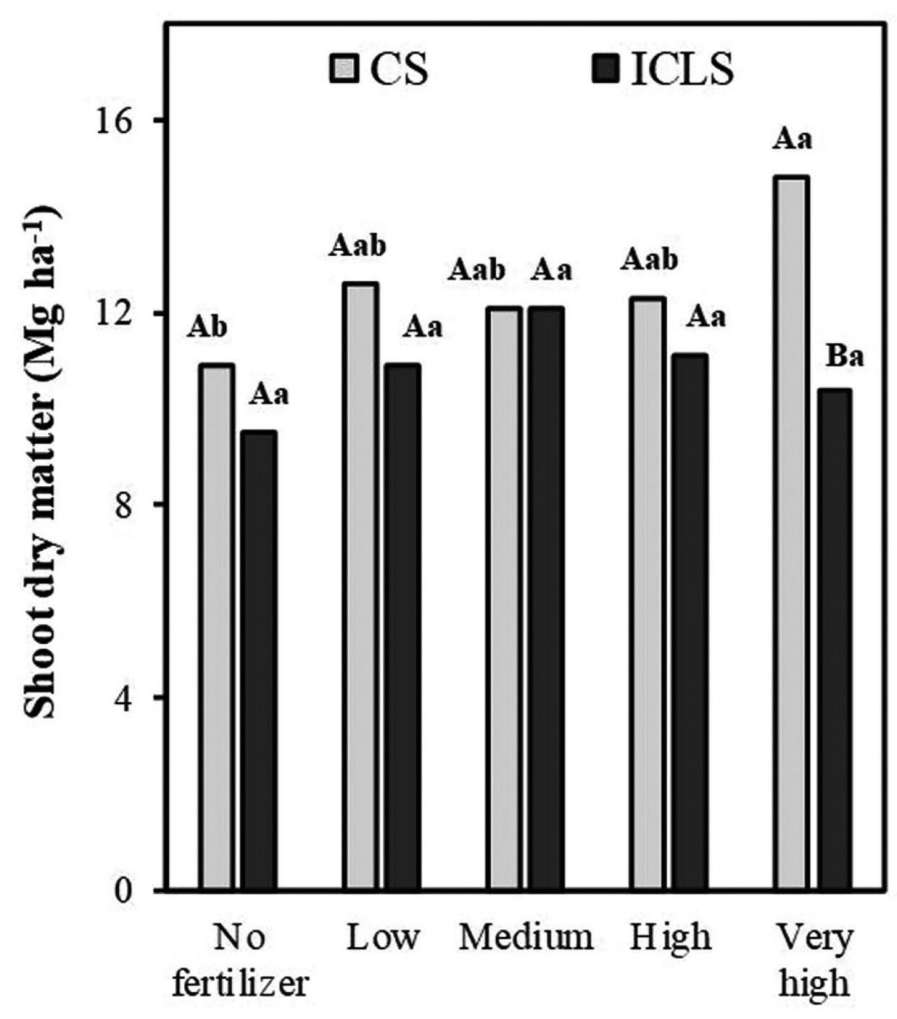

Fertilization level

Figure 2 Flooded rice shoot dry matter affected by fertilization levels in the 2015/2016 cropping season of different production systems in the Brazilian subtropics. Tukey's test $(p<.05)$. Different lowercase letters indicate differences among the fertilization levels within each flooded rice production system; different uppercase letters indicate differences between flooded rice production systems within each fertilization level. CS, conventional system; ICLS, integrated crop-livestock system.

systems were observed only in the very high fertilization level, resulting in an increase of $0.5 \mathrm{Mg} \mathrm{ha}^{-1}$ in CS when compared with ICLS (Figure 2).

Increases in rice yield due to fertilization levels were observed in both production systems (Figure 3). In the CS, all fertilizer rates were higher than the no-fertilizer treatment, and the highest yield ( $\left.9.7 \mathrm{Mg} \mathrm{ha}^{-1}\right)$ was obtained in the very high fertilization level (3.2 $\mathrm{Mg} \mathrm{ha}^{-1}$ higher than the treatment without fertilization). The low and medium fertilization levels showed intermediate values of 8.5 and $8.7 \mathrm{Mg} \mathrm{ha}^{-1}$, respectively.

On the other hand, the grain yield of flooded rice under ICLS did respond to fertilizer levels (Figure 3). Under ICLS, the low fertilization level yielded $8.5 \mathrm{Mg} \mathrm{ha}^{-1}$, which was not different from the control $(7.9 \mathrm{Mg}$ 


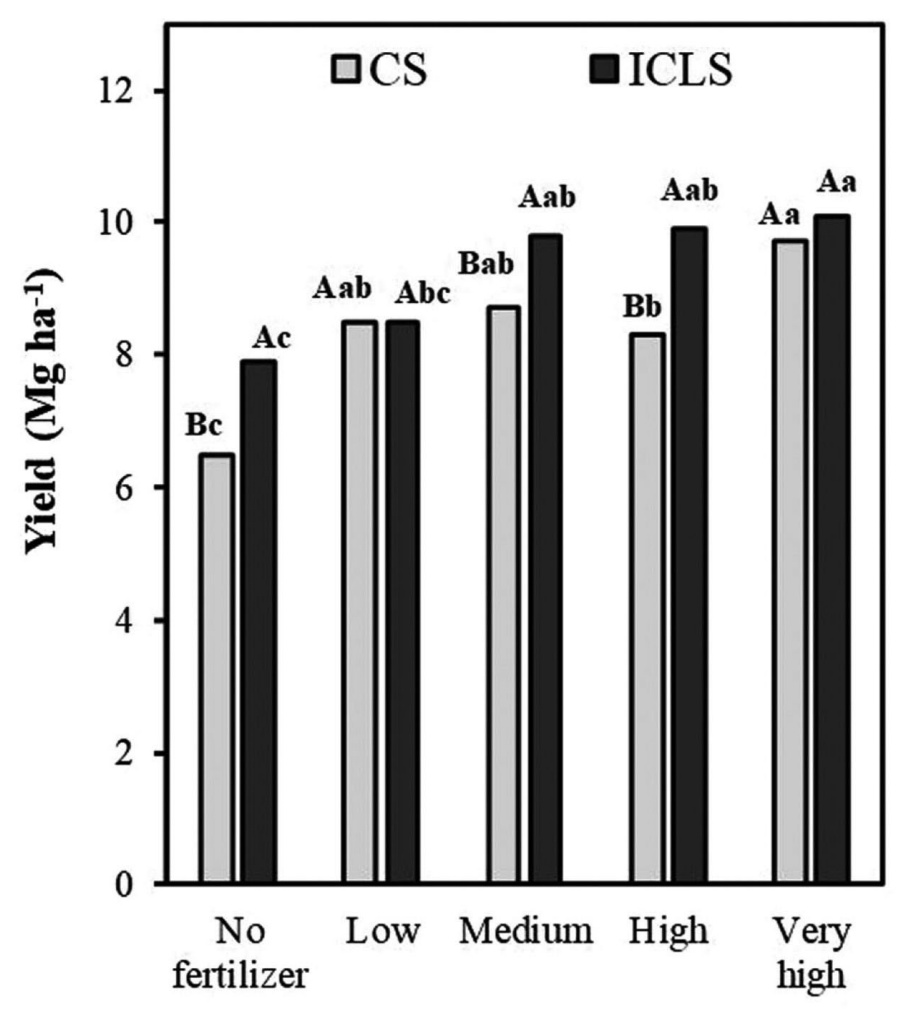

Fertilization level

Figure 3 Flooded rice grain yield affected by fertilization levels in the 2015/2016 cropping season of different production systems in the Brazilian subtropics. Tukey's test $(p<.05)$. Different lowercase letters indicate differences among the fertilization levels within each flooded rice production system; different uppercase letters indicate differences between flooded rice production systems within each fertilization level. CS, conventional system; ICLS, integrated crop-livestock system.

$\left.\mathrm{ha}^{-1}\right)$. The medium and high fertilization levels presented intermediate grain yields (9.8 and $9.9 \mathrm{Mg} \mathrm{ha}^{-1}$, respectively) compared with low and very high fertilization levels and were similar between themselves. The very high fertilization level showed the highest yield $\left(10.1 \mathrm{Mg} \mathrm{ha}^{-1}\right)$ and was significantly higher than both the control (no-fertilizer) and low fertilization level. Finally, the ICLS showed higher yield compared with the CS in most of the fertilization levels, except for the low and very high fertilizer rates. In the no-fertilizer control and with medium and high fertilization levels, ICLS yielded 1.4, 1.1, and $1.6 \mathrm{Mg} \mathrm{ha}^{-1}$ more than CS, respectively (Figure 3). 


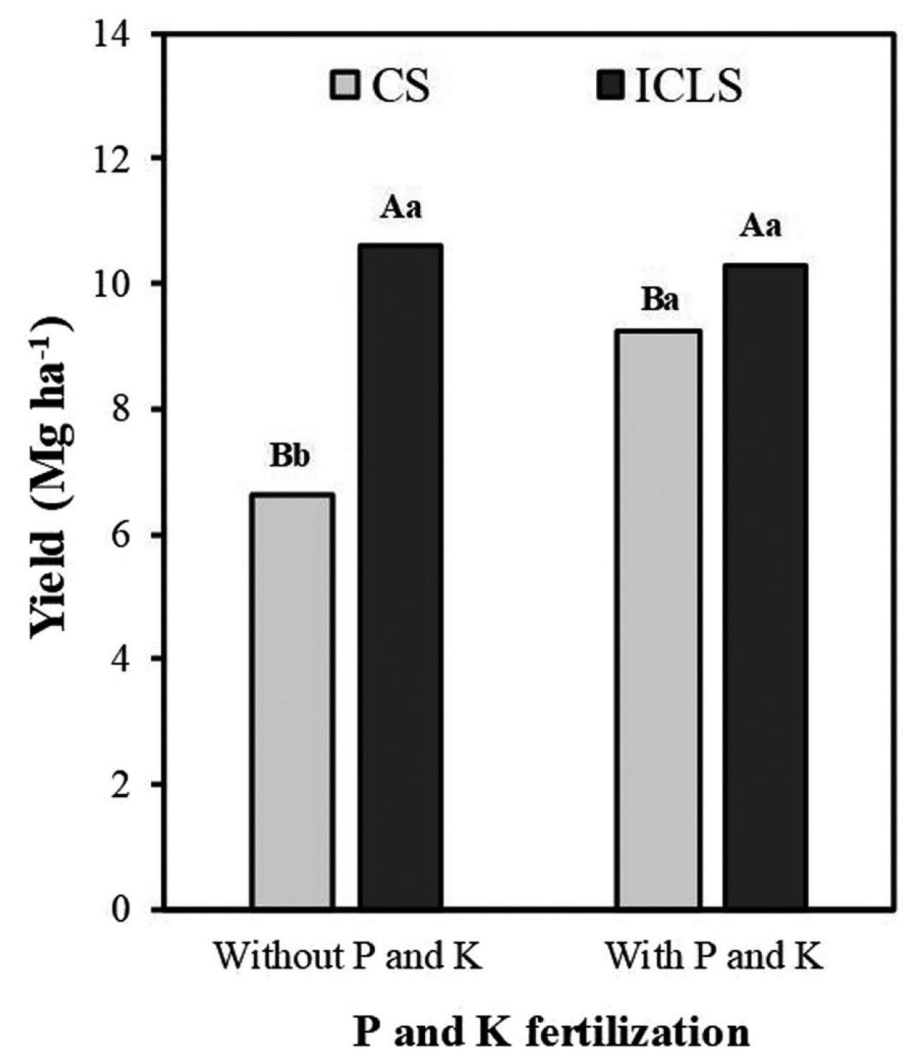

Figure 4 Flooded rice grain yield with or without $\mathrm{P}$ and $\mathrm{K}$ fertilization in the 2016/2017 cropping season in different production systems in the Brazilian subtropics. Tukey's test $(p<.05)$. Different lowercase letters indicate differences between the $\mathrm{P}$ and $\mathrm{K}$ fertilization within each flooded rice production system; different uppercase letters indicate differences between flooded rice production systems within each $\mathrm{P}$ and $\mathrm{K}$ fertilization.

Regarding the second cropping season evaluated (2016/2017), P and $\mathrm{K}$ supply did not affect rice yield in ICLS, which showed an average yield of $10.5 \mathrm{Mg} \mathrm{ha}^{-1}$ (Figure 4). On the other hand, rice yield in CS was increased by almost $40 \%$ by $\mathrm{P}$ and $\mathrm{K}$ fertilization. The rice yield was higher in ICLS than in CS both with and without P and K fertilization. Whereas without $\mathrm{P}$ and $\mathrm{K}$ fertilization the yield difference between ICLS and CS was $4 \mathrm{Mg} \mathrm{ha}^{-1}$, with $\mathrm{P}$ and $\mathrm{K}$ this difference was $1.1 \mathrm{Mg} \mathrm{ha}^{-1}$ (Figure 4).

In contrast to $\mathrm{P}$ and $\mathrm{K}, \mathrm{N}$ rates affected rice yield in both systems (Table 3). On average over the production systems, the $150 \mathrm{~kg} \mathrm{~N} \mathrm{ha}^{-1}$ rate increased rice yield by $1.7 \mathrm{Mg} \mathrm{ha}^{-1}$. The 50 and $100 \mathrm{~kg} \mathrm{~N}^{-1}$ rates presented intermediate rice yields of 8.8 and $9.4 \mathrm{Mg} \mathrm{ha}^{-1}$, respectively, and did not differ from the other $\mathrm{N}$ rates. Although both systems showed 
Table 3 Flooded rice grain yield affected by nitrogen supply levels in the 2016/2017 cropping season in different production systems in the Brazilian subtropics

\begin{tabular}{lccccc} 
& \multicolumn{5}{c}{$\begin{array}{c}\text { Nitrogen supply } \\
\text { kg N ha }\end{array}$} \\
\cline { 2 - 5 } Production system $^{\mathbf{a}}$ & 0 & 50 & 100 & 150 & Average \\
\cline { 2 - 5 } CS & 7.2 & 7.8 & 8.7 & 9.3 & $8.3 \mathrm{~B}$ \\
ICLS & 8.7 & 9.8 & 10.0 & 10.2 & $9.7 \mathrm{~A}$ \\
Average & $8.0 \mathrm{~b}$ & $8.8 \mathrm{ab}$ & $9.4 \mathrm{ab}$ & $9.7 \mathrm{a}$ & \\
\hline
\end{tabular}

Tukey's test $(p<.05)$. Different lowercase letters indicate differences among the nitrogen supply levels within each flooded rice production system. Different uppercase letters indicate differences between flooded rice production systems within each nitrogen supply level.

a. CS, conventional system; ICLS, integrated crop-livestock system.

response to $\mathrm{N}$ rates, the ICLS had a higher yield than CS at all $\mathrm{N}$ rates, with a mean yield that was $1.4 \mathrm{Mg} \mathrm{ha}^{-1}$ higher than CS (Table 3).

\subsubsection{Nutrient use efficiency}

Only $\mathrm{N}$ efficiency was affected by fertilization levels and production systems (Table 4). The highest efficiency was found in the absence of fertilization, with $90.9 \mathrm{~kg}$ of grain produced per kilogram of $\mathrm{N}$ accumu-

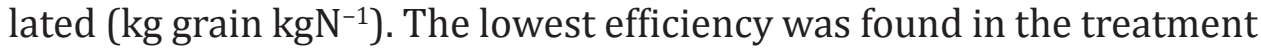
with medium fertilization level (69.5 $\mathrm{kg}_{\text {grain }} \mathrm{kg} \mathrm{N}^{-1}$ ), whereas the other fertilization levels showed similar efficiencies $\left(77.8 \mathrm{~kg}_{\text {grain }} \mathrm{kg} \mathrm{N}^{-1}\right)$. On average, ICLS was more efficient than CS, yielding $>23 \mathrm{~kg}_{\text {grain }} \mathrm{kg} \mathrm{N}^{-1}$. In the same way, the ICLS yielded 30 and $27 \%$, respectively, more grain than the CS with the same amount of accumulated P and $\mathrm{K}$ in the shoot biomass.

The relationship established between flooded rice grain yield and nutrient accumulation in shoot dry matter shows that, regardless of the nutrient (N, P, or K), with the same amount of nutrient accumulated there are always higher yields in the ICLS than in the CS (Figure 5). The correlation between these two variables was similar between the systems only considering the $\mathrm{N}$ accumulated, with $R^{2}$ values of .81 for CS and .79 for ICLS. For P and K, only CS presents an $R^{2}$ of 88 for both nutrients. The ICLS has a lower relation between accumulated $\mathrm{P}$ and $\mathrm{K}$ and grain yield, with $R^{2}$ values of .49 and 0.34 for $\mathrm{P}$ and $\mathrm{K}$, respectively. 
Table 4 Flooded rice grain yield per each $\mathrm{kg}$ of N, P, and $\mathrm{K}$ accumulated in shoot dry matter in the $2015 / 2016$ cropping season, affected by

fertilization levels in different production systems in the Brazilian subtropics

\begin{tabular}{|c|c|c|c|c|c|c|}
\hline \multirow{2}{*}{$\begin{array}{l}\text { Production } \\
\text { system }\end{array}$} & \multicolumn{5}{|c|}{ Fertilization level } & \multirow[b]{2}{*}{ Average } \\
\hline & No fertilizer & Low & Medium & High & Very high & \\
\hline \multicolumn{7}{|c|}{ Nitrogen (kg grain $\mathrm{kg} \mathrm{N}^{-1}$ ) } \\
\hline CS & 74.3 & 58.8 & 63.5 & 61.7 & 77.9 & $67.3 \mathrm{~B}$ \\
\hline ICLS & 107.5 & 91.3 & 75.5 & 92.2 & 84.9 & $90.3 \mathrm{~A}$ \\
\hline Average & $90.9 a$ & $75.0 \mathrm{ab}$ & $69.5 b$ & 77.0ab & $81.4 \mathrm{ab}$ & \\
\hline \multicolumn{7}{|c|}{ Phosphorus (kg grain $\mathrm{kg} \mathrm{P}^{-1}$ ) } \\
\hline CS & 229.2 & 207.2 & 248.8 & 247.2 & 244.8 & $235.5 B$ \\
\hline ICLS & 286.9 & 299.3 & 286.3 & 306.9 & 357.5 & $307.4 \mathrm{~A}$ \\
\hline Average & $258.1 \mathrm{~ns}$ & 253.3 & 267.6 & 277.1 & 301.2 & \\
\hline \multicolumn{7}{|c|}{ Potassium ( $\mathrm{kg}$ grain $\mathrm{kg} \mathrm{K}^{-1}$ ) } \\
\hline CS & 36.9 & 36.8 & 41.6 & 44.5 & 46.2 & $41.2 \mathrm{~B}$ \\
\hline ICLS & 51.3 & 48.0 & 50.9 & 59.3 & 52.8 & $52.5 \mathrm{~A}$ \\
\hline Average & $44.1 \mathrm{~ns}$ & 42.4 & 46.2 & 51.9 & 49.5 & \\
\hline
\end{tabular}

Tukey's test $(p<.05)$. Different lowercase letters indicate differences among the fertilization levels within each flooded rice production system. Different uppercase letters indicate differences between flooded rice production systems within each fertilization level. ns, no statistical difference.
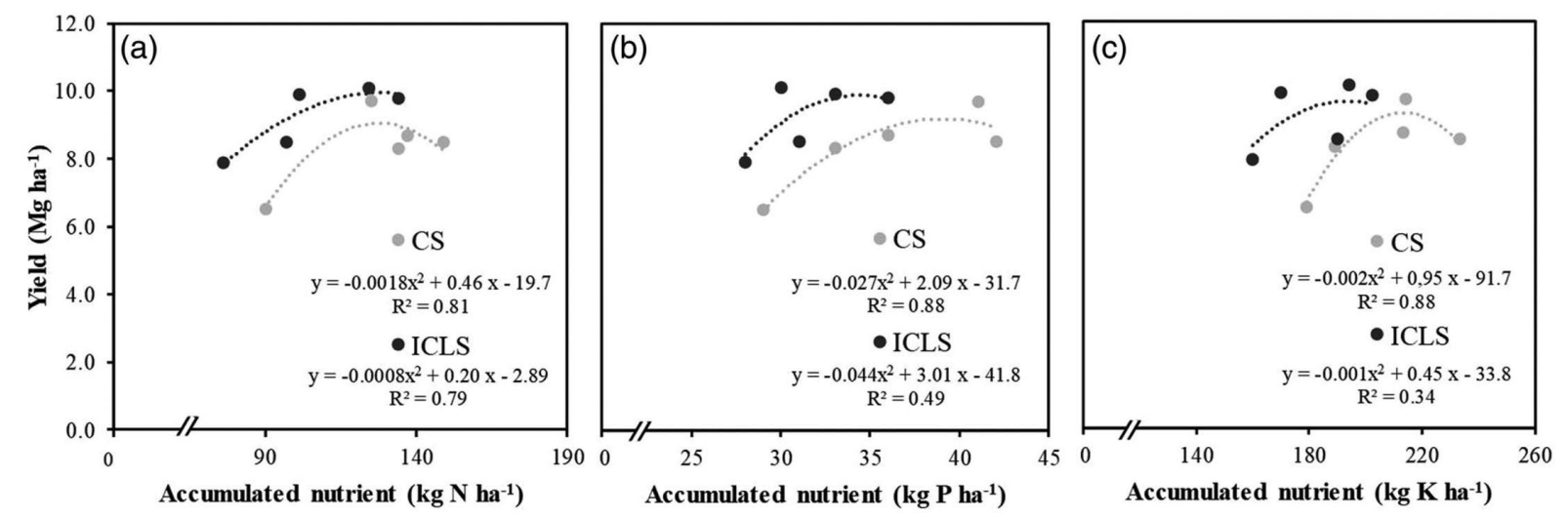

Figure 5 Relationship between flooded rice yield and (a) N, (b) P, and (c) K accumulated in shoot dry matter, affected by fertilization levels in the 2015/2016 cropping season in different production systems in the Brazilian subtropics. CS, conventional system; ICLS, integrated crop-livestock system. 


\section{Discussion}

The traditional paddy field system in the Brazilian subtropics is based on intensive soil disturbance (SOSBAI, 2018), which results in high levels of soil degradation (Boeni et al., 2010). Alternatives, like the longterm adoption of no-tillage, have arisen as important tools to improve soil quality in the paddy fields (Denardin et al., 2019). However, we observed improvements in soil chemical attributes under ICLS in the short term. After 30 mo of ICLS adoption, higher soil P content was observed under ICLS compared with CS (Table 1). Although tendencies of higher SOM content under ICLS (0.4\%) compared with CS (0.2\%) could already be noted, no statistically significant differences could be observed. Thus, soils under ICLS and CS would both be classified as having low SOM content $(<2.5 \%)$, very high $\mathrm{P}$ content $\left(>12 \mathrm{mg} \mathrm{dm}^{-3}\right)$, and high $\mathrm{K}$ content (91-180 $\mathrm{mg} \mathrm{dm}^{-3}$ ), according to soil chemical fertility for flooded rice cultivation (CQFS RS/SC, 2016). Therefore, theoretically, the same yield response to fertilization would be expected (SOSBAI, 2018) from both systems.

Despite the similarity regarding soil chemical analysis for both systems, which would indicate the same fertilizer requirement, the ICLS showed higher yields in almost all evaluated fertilizations rates (Figures 3 and 4; Table 3); these yields were consequently higher in NUE than CS (Table 4). Our results are in agreement with Dalal, Wang, Allen, Reeves, and Menzies (2011) and Martins et al. (2014), who found higher NUE through no-tillage and ICLS adoption, respectively. Greater NUE was also identified in the ICLS yield compared with CS when no fertilizer was provided (Figure 3). Also, the NUE in ICLS was observed in similar yields under the medium fertilization level compared with high and very high fertilization levels (Figure 3), saving up to $60 \mathrm{~kg} \mathrm{~N} \mathrm{ha}^{-1}, 20 \mathrm{~kg} \mathrm{P}_{2} \mathrm{O}_{5}$ ha $^{-1}$, and $30 \mathrm{~kg} \mathrm{~K}_{2} \mathrm{O} \mathrm{ha}^{-1}$ in the flooded rice cultivation.

Rice yield under ICLS did not respond to $\mathrm{P}$ and $\mathrm{K}$ fertilization (Figure 4), which may be related to nutrient cycling (Assmann et al., 2017), which was favored by the large amount of animal and plant residues under ICLS (Bayer, L., Mielniczuk, Pavinato, \& Dieckow, 2006; Schoenau \& Campbell, 1996; Thomas, Dalal, \& Standley, 2007). Therefore, because the animal exports a minimum amount of nutrients through meat (Whitehead, 2000), the replenishment of $\mathrm{P}$ and $\mathrm{K}$ exported by rice grains can be performed on successive pastures. This may be a more 
efficient alternative method of fertilization with $\mathrm{P}$ and $\mathrm{K}$ for rice cultivation under ICLS.

Different from that observed for $\mathrm{P}$ and $\mathrm{K}$ fertilization, rice yield responds to $\mathrm{N}$ fertilization in both production systems (Table 3). However, ICLS had a yield $17 \%$ higher (1.4 $\mathrm{Mg} \mathrm{ha}^{-1}$ ) than CS, possibly due to higher SOM labile fraction in this system, as observed by Martins et al. (2017). According to Denardin et al. (2019), the $\mathrm{N}$ deficiency remains as the main limitation of rice yield with adoption of no-tillage alone. Normally, $\mathrm{N}$ is the most limiting nutrient in systems with high residue amounts, and this is due to the greater advantage and capacity of the soil microorganisms for $\mathrm{N}$ uptake compared with plant roots across any concentration range (Geisseler, Horwath, Joergensen, \& Ludwig, 2010; Kuzyakov \& Xu, 2013; Liu et al., 2016).

In the present study, $66 \%$ of $\mathrm{N}$ fertilizer was applied at the $\mathrm{V}_{3}$ rice stage to stimulate tillering (plant growth). Under CS, N addition is mostly converted to plant growth, and $\mathrm{N}$ dynamics may be different under ICLS due to the greater residue accumulation with a high $\mathrm{C} / \mathrm{N}$ ratio on the soil surface, which can favor great $\mathrm{N}$ immobilization by soil microorganisms (Gómez-Rey, Couto-Vázquez, \& González-Prieto, 2012; Kuzyakov \& Xu, 2013; Singh, Shan, Johnson-Beebout, Singh, \& Buresh, 2008). As a result, $\mathrm{N}$ added can be initially less available to plant growth leading to lower shoot dry matter production under ICLS (Figure 2). This explains why we observed higher rice yield but lower shoot dry matter under ICLS, resulting in higher NUE compared with CS.

Higher yields observed under ICLS are also possibly related to greater synchronism between $\mathrm{N}$ uptake by rice and $\mathrm{N}$ released from soil and microorganisms (because immobilized $\mathrm{N}$ becomes available for rice after death of microorganisms) compared with CS (Kuzyakov \& Xu, 2013; Liu et al., 2016). Short immobilization of mineral $\mathrm{N}$ by microorganisms is an important adaptation of ecosystems, and the allocation of $\mathrm{N}$ within soil microorganisms protects against losses, such as $\mathrm{N}$ leaching or denitrification (Kuzyakov \& Xu, 2013). Consequently, ICLS is less susceptible to $\mathrm{N}$ losses, and rice in ICLS is more efficient in converting $\mathrm{N}$ to grain in relation to $\mathrm{CS}$.

The results of flag leaf analysis, which is widely used as a reference to evaluate rice nutritional status, showed in both systems an adequate nutritional status for $\mathrm{N}$ (range, 23-28 $\mathrm{g} \mathrm{N} \mathrm{kg}^{-1}$ ) (Figure 1) and above-adequate nutritional status for $\mathrm{P}$ and $\mathrm{K}\left(>2.5 \mathrm{~g} \mathrm{P} \mathrm{kg}^{-1},>14 \mathrm{~g} \mathrm{~K} \mathrm{~kg}^{-1}\right.$, respectively) 
(SOSBAI, 2018). This fact is probably due to the $\mathrm{P}$ and $\mathrm{K}$ luxury consumption by rice (i.e., when a plant continues to uptake nutrients without reflecting in higher yield) (Burgos, Norman, Gealy, \& Black, 2006; Dobermann, Cassman, Cruz, Adviento, \& Pampolino, 1996; Zou, Daozhu, Minggang, Huaping, \& Boren, 2001), especially under high content of these nutrients in the soil. According to Dobermann and Fairhurst (2000), the relationship between grain yield and nutrient uptake that reveals an optimal internal NUE is 68, 385, and $69 \mathrm{~kg}$ grain yielded per kilogram of $\mathrm{N}$, $\mathrm{P}$, and $\mathrm{K}$ accumulated in the rice shoot biomass, respectively. Considering $\mathrm{N}$, rice cultivated under CS showed an optimal internal NUE, with $67.3 \mathrm{~kg}$ grain $\mathrm{kg}^{-1} \mathrm{~N}$. Rice cultivated under ICLS was more efficient, yielding 90.0 $\mathrm{kg}$ grain per $\mathrm{kg} \mathrm{N}$ accumulated in shoot biomass (Table 4).

Both systems were inefficient in the use of $\mathrm{P}$ and $\mathrm{K}$, yielding 235.5 and $307.4 \mathrm{~kg}$ grain per kilogram $\mathrm{P}$ and 41.2 and $52.5 \mathrm{~kg}$ grain per kilogram $\mathrm{K}$ accumulated in shoot biomass in CS and ICLS, respectively (Dobermann \& Fairhurst, 2000) (Table 4). However, ICLS was more efficient than CS, yielding 30 and $27 \%$ more grain, respectively, with the same amount of accumulated $\mathrm{P}$ and $\mathrm{K}$ in the shoot biomass. Nitrogen uptake is directly related to plant biomass production (Marschner, 2011) and consequently to the uptake of other nutrients, such as $\mathrm{P}$ and $\mathrm{K}$. Thus, the higher availability of initial $\mathrm{N}$ for rice under $\mathrm{CS}$ possibly resulted in higher biomass production and $\mathrm{P}$ and $\mathrm{K}$ uptake, showing lower NUE than ICLS (Table 3). Therefore, in addition to the higher $\mathrm{N}$ use efficiency in ICLS, this system decreases the luxury consumption of other nutrients, thereby increasing $\mathrm{P}$ and $\mathrm{K}$ use efficiency. In this sense, the adoption of ICLS appears to be an appropriate strategy to increase the NUE in paddy fields of the Brazilian subtropical region.

Systems that receive more fertilization and produce more biomass did not guarantee greater rice yield. Thus, efforts to gain a better understanding of the processes regarding nutrient cycling under conservation management systems in rice cultivation, such as ICLS, seem to be necessary to develop new standards of fertilization, aiming to find more efficient systems regarding nutrient use and with less dependence on external inputs. 


\section{Conclusions}

Integrated crop-livestock systems and CS have different yield responses to fertilization levels, even with the same interpretation of soil fertility levels. Flooded rice under ICLS yields more grain while requiring lower fertilizer application than CS. The ICLS has higher NUE compared with CS, demonstrated by the greater use efficiency of nutrients, yielding a higher amount of grain with the same amount of nutrient uptake. Rice yield under ICLS does not respond to $\mathrm{P}$ and $\mathrm{K}$ fertilization supply, suggesting an important contribution of nutrient cycling to plant nutrition. However, $\mathrm{N}$ remains a limiting nutrient for development and production of flooded rice.

Efforts to gain a better understanding of the processes regarding nutrient cycling under ICLS seem to be necessary to develop new standards of fertilization, aiming to find more efficient systems regarding nutrient use and with less dependence on external inputs.

Acknowledgments This research was funded by a grant from the Agrisus foundation (Project no. PA 2337/18). We thank this foundation, which always supports research aimed at sustainable intensification of Brazilian agricultural production; the National Council for the Development of Science and Technology (CNPq) for scholarship support; the staff of Corticeiras Farm for field support; and Braden Thue for support in correcting English.

Funding information Fundação Agrisus, Grant/Award Number: 2337/18

\section{References}

Alexandratos, N., \& Bruinsma, J. (2003). World agriculture: Towards 2015/2030: An FAO perspective. Land Use Policy, 20, 375-380. https://doi.org/10.1016/S02648377(03)00047-4

Assmann, J. M., Martins, A. P., Anghinoni, I., Denardin, L.G.O., Nichel, G. H., Andrade Costa, S. E. V. G., ... Franzluebbers, A. J. (2017). Phosphorus and potassium cycling in a long-term no-till integrated soybean-beef cattle production system under different grazing intensities in subtropics. Nutrient Cycling in Agroecosystems, 108, 1-13. https://doi.org/10.1007/s10705-016-9818-6

Bado, B. V., Aw, A., \& Ndiaye, M. (2010). Long-term effect of continuous cropping of irrigated rice on soil and yield trends in the Sahel of West Africa. Nutrient Cycling in Agroecosystems, 88, 133-141. https://doi.org/10.1007/s10705-010-9355-7 
Bayer, C., Martin-Neto, L., Mielniczuk, J., Pavinato, A., \& Dieckow, J. (2006). Carbon sequestration in two Brazilian Cerrado soils under notill. Soil and Tillage Research, 86, 237-245. https://doi.org/10.1016/j.still.2005.02.023

Bijay-Singh, B., Shan, Y. H., Johnson-Beebout, S. E., Singh, Y., \& Buresh, R. J. (2008). Crop residue management for lowland rice-based cropping systems in Asia. Advances in Agronomy, 98, 117-199. https://doi.org/10.1016/S00652113(08)00203-4

Boeni, M., Anghinoni, I., Genro Junior, S. A., \& Osório Filho, B. D. (2010). Evolução da fertilidade dos solos cultivados com arroz irrigado no Rio Grande do Sul. Cachoeirinha, Rio Grande do Sul, Brazil: IRGA.

Burgos, N. R., Norman, R. J., Gealy, D. R., \& Black, H. (2006). Competitive N uptake between rice and weedy rice. Field Crop Research, 99, 96-105. https://doi. org/10.1016/i.fcr.2006.03.009

Carmona, F. C., Anghinoni, I., Mezzari, C. P., Martins, A. P., \& Carvalho, P. C. F. (2016). Effectiveness of current fertilizer recommendations for irrigated rice in integrated crop-livestock systems. Revista Brasileira de Ciência do Solo, 40, 1-8. https://doi.org/10.1590/18069657rbcs20140798

Carvalho, P. C. F., Moraes, A., Pontes, L. S., Anghinoni, I., Sulc, R. M., \& Batello, C. (2014). Definições e terminologias para Sistema Integrado de Produção Agropecuária. Revista Ciência Agronômica, 5, 1040-1046. https://doi. org/10.1590/S1806-66902014000500020

Carvalho, P. C. F., Anghinoni, I., Moraes, A., Souza, E. D., Sulc, R. M., Lang, C. R., ... Bayer, C. (2010). Managing grazing animals to achieve nutrient cycling and soil improvement in no-till integrated systems. Nutrient Cycling in Agroecosystems, 88, 259-273. https://doi.org/10.1007/s10705-010-9360-x

Cassman, K. G., De Datta, S. K., Olk, D. C., Alcantara, J. M., Samson, M. I. et al. (1995). Yield decline and the nitrogen economy of long-term experiments on continuous, irrigated rice systems in the tropics. In: R. Lal \& B. A. Stewart (Eds.), Soil management: Experimental basis for sustainability and environmental quality (pp. 181-222). Boca Raton, FL: Lewis Publishers.

Counce, P., Keisling, T. C., \& Mitchell, A. J. (2000). A uniform, objective, and adaptive system for expressing rice development. Crop Science, 40, 436-443.

Commission of Chemistry and Soil Fertility (CQFS RS/SC). (2004). Manual de adubação e de calagem para os estados do Rio Grande do Sul e Santa Catarina. Porto Alegre, Rio Grande do Sul, Brazil: Sociedade Brasileira de Ciência do Solo.

Commission of Chemistry and Soil Fertility (CQFS-RS/SC). (2016). Manual de calagem e adubação para os Estados do Rio Grande do Sul e Santa Catarina. Rio Grande do Sul, Brazil: SBCSNRS/EMBRAPA-CNPT.

Dalal, R. C., Wang, W., Allen, D. E., Reeves, S., \& Menzies, N. W. (2011). Soil nitrogen and nitrogen-use efficiency under long-term no-till practice. Soil Science Society of America Journal, 75, 2251-2261. https://doi.org/10.2136/sssaj2010.0398 
Denardin, L. G. O., Carmona, F. C., Veloso, M. G., Martins, A. P., Freitas, T. F. S., Carlos, F. S., ... Anghinoni, I. (2019). No-tillage increases irrigated rice yield through soil quality improvement along time. Soil and Tillage Research, 186, 64-69. https:// doi.org/10.1016/j.still.2018.10.006

Denardin, L. G. O., Martins, A. P., Carlos, F. S., Anghinoni, I., Moojen, F. G., Borin, J. B. M., ... Carvalho, P. C. F. (2018). Geração do conhecimento. In F. C. Carmona, L. G. O. Denardin, A. P. Martins, I. Anghinoni, \& C. F. Carvalho (Eds.), Sistemas integrados de produção agropecuária em Terras Baixas (1st ed., pp. 39-100). Porto Alegre, Rio Grande do Sul, Brazil: UFRGS.

Dobermann, A., Cassman, K. G., Cruz, P. C. S., Adviento, M., \& Pampolino, M. F. (1996). Fertilizer inputs, nutrient balance, and soil nutrient-supplying power in intensive, irrigated rice systems: II. Effective soil K-supplying capacity. Nutrient Cycling in Agroecosystems, 46, 11-21.

Dobermann, A., Dawe, D., Roetter, R. P., \& Cassman, K. G. (2000). Reversal of rice yield decline in a long-term continuous cropping experiment. Agronomy Journal, 92, 633-643. https://doi.org/10.2134/agronj2000.924633x

Dobermann, A., \& Fairhurst, T. (2000). Rice: Nutrient disorders \& nutrient management. IPNI Canada.

Food and Agriculture Organization of the United Nations Statistics (FAOSTAT). (2013). Crops. Retrieved from http://faostat3.fao.org/browse/Q/QC/E

Feng, Y., Zou, Y., Buresh, R. J., Xu, G., Ao, H., \& Wang, S. (2006). Effects of no-tillage and direct broadcasting on soil physical and chemical properties and growth and yield formation in hybrid rice. Acta Ecologica Sinica, 32, 1728-1736.

Flinn, J. C., \& De Datta, S. K. (1984). Trends in irrigated-rice yields under intensive cropping at Philippine research stations. Field Crops Research, 9, 1-15. https:// doi.org/10.1016/0378-4290(84)90002-9

Gao, M., Zhou, B., Wei, C., Xie, D., \& Zhang, L. (2000). Effect of tillage system on soil animal, microorganism and enzyme activity in paddy field. Chinese Journal of Applied Ecology, 15, 1177-1181.

Geisseler, D., Horwath, W. R., Joergensen, R. G., \& Ludwig, B. (2010). Pathways of nitrogen utilization by soil microorganisms: A review. Soil Biology \& Biochemistry, 42, 2058-2067. https://doi.org/10.1016/j.soilbio.2010.08.021

Gómez-Rey, M. X., Couto-Vázquez, A., \& González-Prieto, S. J. (2012). Nitrogen transformation rates and nutrient availability under conventional plough and conservation tillage. Soil and Tillage Research, 124, 144-152. https://doi. org/10.1016/j.still.2003.12.002

Huang, M., Zhou, X., Cao, F., Xia, B., \& Zou, Y. (2015). No-tillage effect on rice yield in China: A meta-analysis. Field Crops Research, 183, 126-137. https://doi. org/10.1016/i.fcr.2015.07.022

Kaminski, J., Rheinheimer, D. S., \& Bartz, H. R. (2001). Proposta de nova equação para determinação do valor de H+Al pelo uso do índice SMP em solos do RS e SC. Frederico Westphalen, Rio Grande do Sul, Brazil: ANAIS: Reunião Anual da ROLAS. 
Khush, G. S. (2000). Strategies for increasing the yield potential of rice. Studies in Plant Science, 7, 207-212. https://doi.org/10.1016/S0928-3420(00)80016-6

Kottek, M., Grieser, J., Beck, C., Rudolf, B., \& Rubel, F. (2006). World map of the Köppen-Geiger climate classification updated. Meteorologische Zeitschrift, 15, 259-263. https://doi.org/10.1127/0941-2948/2006/0130

Kuzyakov, Y., \& Xu, X. (2013). Competition between roots and microorganisms for nitrogen: Mechanisms and ecological relevance. New Phytologist, 198, 656-669. https://doi.org/10.1111/nph.12235

Lal, R. (2015). Restoring soil quality to mitigate soil degradation. Sustainability, 7, 5875-5895. https://doi.org/10.3390/su7055875

Liu, Q., Qiao, N., Xu, X., Xin, X., Han, J. Y., Tian, Y., ... Kuzyakov, Y. (2016). Nitrogen acquisition by plants and microorganisms in a temperate grassland. Scientific Reports, 6, 22642. https://doi.org/10.1038/srep22642

Marschner, H. (2011). Marschner's mineral nutrition of higher plants (3rd ed). Cambridge, MA: Academic Press.

Martins, A. P., Costa, S. E. V. G. A., Anghinoni, I., Kunrath, T. R., Balerini, F., Cecagno, D., ... Carvalho P. C. F. (2014). Soil acidification and basic cation use efficiency in an integrated no-till crop-livestock system under different grazing intensities. Agriculture, Ecosystems \& Environment, 195, 18-28. https://doi.org/10.1016/i. agee.2014.05.012

Martins, A. P., Denardin, L. G. O., Borin, J. B. M., Carlos, F. S., Barros, T., Ozório, D. V. B., ... Carvalho, P. C. F. (2017). Short-term impacts on soil-quality Assessment in alternative land uses of traditional paddy fields in southern Brazil. Degradation \& Development, 28, 534-542. https://doi.org/10.1002/ldr.2640

Matzenauer, R., Radin, B., \& Almeida, I. R. 2011. Atlas climático: Rio Grande do Sul. Porto Alegre, Rio Grande do Sul, Brazil: Fundação Estadual de Pesquisa Agropecuária.

SAS Institute. (1997). Changes and enhancements through release 1 6.12. Cary, NC: SAS Institute.

Schoenau, J. J., \& Campbell, C. A. (1996). Impact of crop residues on nutrient availability in conservation tillage systems. Canadian Journal of Plant Science, 76, 621-626. https://doi.org/10.4141/cjps96-111

Soil Survey Staff. (2010). Keys to soil taxonomy. Washington, DC: USDA-NRCS.

SOSBAI. (2014). Arroz irrigado: Recomendações técnicas da pesquisa para o Sul do Brasil. Pelotas, Rio Grande do Sul, Brazil: SOSBAI.

SOSBAI. (2018). Arroz irrigado: Recomendações técnicas da pesquisa para o Sul do Brasil. Farroupilha, Rio Grande do Sul, Brazil: SOSBAI.

Tang, X., Shao, J. A., Gao, M., Wei, C. F., Xie, D. T., \& Pan, G. X. (2007). Effects of conservational tillage on aggregate composition and organic carbon storage in purple paddy soil. Chinese Journal of Applied Ecology, 18, 1027-1032.

Tedesco, M. J., Gianello, C., Bissani, C. A., Bohnen, H., \& Volkweiss, S. J. (1995). Análises de solo, plantas e outros materiais. Porto Alegre, Rio Grande do Sul, Brazil: UFRGS. 
Thomas, G. A., Dalal, R. C., \& Standley, J. (2007). No-till effects on organic matter, pH, cation exchange capacity and nutrient distribution in a Luvisol in the semi-arid subtropics. Soil and Tillage Research, 94, 295-304. https://doi.org/10.1016/j. still.2006.08.005

Whitehead, D. C. (2000). Nutrient elements in grassland. Wallingford, UK: CABI Publishing.

Zou, C., Daozhu, Q., Minggang, X., Huaping, S., \& Boren, W. (2001). Nitrogen, phosphorous and potassium uptake characteristics of rice and its relationship with grain yield. Journal-Nanjing Agricultural University, 25, 6-10. 